\title{
Users Satisfaction Toward Learning Space Services Quality at Tunku Tun Aminah Library (Technical University's Library): A Case Study
}

\author{
Muhamad Saufi Che Rusuli ${ }^{1}$, Norlizawati Yusof ${ }^{2}$, Safiee Idris $^{2}$, Rosmaini Tasmin ${ }^{3}$, \\ Norazlin Hashim ${ }^{4}$, Sphend Imeri ${ }^{5}$ \\ ${ }^{1}$ Tunku Tun Aminah Library, Universiti Tun Hussein Onn Malaysia, Johor, Malaysia \\ ${ }^{2}$ Faculty of Technical and Vocational Education, Universiti Tun Hussein Onn Malaysia, Johor, Malaysia \\ ${ }^{3}$ Faculty of Technology Management and Business, Universiti Tun Hussein Onn Malaysia, Johor, Malaysia \\ ${ }^{4}$ Centre of Diploma Studies, Universiti Tun Hussein Onn Malaysia, Johor, Malaysia \\ ${ }^{5}$ High Level Training Institute, Gostivar, Macedonia
}

\section{Email address:}

msaufi@uthm.edu.my (M. S. C. Rusuli),norzilawatyusof@gmail (N. Yusof), safiee@uthm.edu.my (S. Idris), rosmaini@uthm.edu.my (R. Tasmin),norazlin@uthm.edu.my (N. Hashim), sphend_85@gmail.com (S. Imeri)

\section{To cite this article:}

Muhamad Saufi Che Rusuli, Norlizawati Yusof, Safiee Idris, Rosmaini Tasmin, Norazlin Hashim, Sphend Imeri. Users Satisfaction Toward Learning Space Services Quality at Tunku Tun Aminah Library (Technical University's Library): A Case Study. International Journal of Vocational Education and Training Research. Vol. 1, No. 1, 2015, pp. 5-9. doi: 10.11648/j.ijvetr.20150101.12

\begin{abstract}
Academic libraries are known as major contributors to students learning on campus, thus, as an important department within higher education institutes and the informal learning space is not known much these days. Therefore, this study strives to discuss about learning space service quality toward user satisfaction at the Tunku Tun Aminah Library (Technical University's Library). Indeed, it is of high importance to determine how the change in space impacts library users such as 'students' perception' of the learning space which incorporates elements. These identified elements of providing normal learning space mainly consist of ventilated facilities, lighting, size, sound effect, colors and furniture. Hence, this study utilized survey as an instrument and randomly distributed to 339 students who have used the library. The data were analyzed by Rasch measurement model (WINSTEP 3.69.1.11) and the results show that library users' were moderatley satisfied with learning space (i.e. Iqra' Room) provided by the library.
\end{abstract}

Keywords: Library, LibQUAL, Rasch Model, User Satisfaction, Library Services

\section{Introduction}

In general most of the universities and other higher education institutes are continuously investing significant amount of funds in order to refurbish and continuously improve existing learning environment facilities to support and enhance learning. Librarians have debated the future of the library as place for more than twenty years. Technological advances (e.g. Space, lighting, ventilation, color, sound effects, furniture and size) shifting institutional perceptions have given increasing urgency to this discussion in recent years [1]. Library is a treasure that not only covers books and sources of information, but libraries can also stimulate intellectual ability and maintain user information resources in order to become a place of gathering information for the future [2,1]. Historically, Tunku Tun Aminah Library began its operation in 1993, when UTHM was known as Pusat Latihan Staf Politeknik (PLSP). With a collection of 5,000 copies of book inherited from the Politeknik Batu Pahat, the PLSP Library occupied a small two-storey building that could accommodate about 120 users. It's mission that time was to support academic staff and students (e.g. technical and vocational) in learning, teaching and research. To accommodate the increasing number of users, the library building has been extended to provide more reading area in year 2000. The extension has increased the floor space for reading to 200 seats. In May 2010, UTHM Library has moved to a new building which has 16,000 square meters of floor area. It can accommodate as many as 300,000 volumes of books and 3,000 users. It provides a spacious and condusive learning environment. It has 100 carrel rooms, 40 discussion rooms, 2 seminar rooms, a post 
graduate research room, an auditorium, a closed reference room, a journal room and a 24 hours reading room. The development of library collection in various fields of study, especially in science and technology, has been intensified to support academic activities. Currently, the library has acquired about 200,000 copies of books, 10,000 titles of thesis, 40 titles of printed journal, 50 titles of magazine and 20,000 items of audio-visual materials. The library has also subscribed the services of 26 databases, 4 e-books and 300 titles of e-journals. The library automation was initiated in 1997 to provide better and faster services. Technically, the student's learning style in the libraries was changing. A study done by Waxman [3] found that students choose to study in informal learning spaces such as coffee bars, cafes, garden parks and so on rather than libraries. Why this is happened and is it because of library rules or learning space in the library? These questions need to be answered by library policy maker to bring new strategy to attract their student into their home. Library facility users" "buy-in" was found to be important in the design process [4]. Hakalal and Nygre'n [5] pointed out that a key objective in the design of university libraries is to answer the question of "how the library can meet its customers' expectations while supporting the parent organization in reaching its objectives".

Nowadays, library members/users can access library content virtually, contact librarians electronically in case of a service need [6]. In this context Hines [7] stated that most of the time users search via a database to search materials that fulfill their needs, and often view the materials online rather than in print. Therefore, the level of facilities and services should be updated so that users can enjoy optimally during the learning process or other activities occur. Furthermore, the user perception of learning space services offered by the library is able to translate the extent to which the services are able to meet the needs of acceptable quality and user satisfaction. This is because the library is seen as a center of innovation, knowledge and culture and the importance of lifelong education of every citizen [8]. Hakalal and Nygre'n [5] believe that libraries are service-producing institutes, and the obvious way of assessing their operations is to measure user satisfaction. User Satisfaction can be defined as an average perceived score exceeding the average desired score and the level of service is higher than desired expectations [9]. Poor service quality indicates to the low valuation of consumer dissatisfaction. Thus, one aspect of the services offer by the libraries can be seen through the provision of learning space. A study conducted by Adnan [10] stated that the provision of space that is not suitable for a conducive learning activity reflects the low quality of the building. Stephen et al. [9] found that for each role, undergraduates, postgraduates, staff and academic staff, the same conclusions hold such as if respondents are satisfied with the level of service dimension, they are satisfied with the library overall. However, if they are dissatisfied with the level of service dimension, they are dissatisfied with the library overall. In addition, there are few studies that have been carried out elaborating the aspects of learning space facility and found that the control room is cramped and disorganized would complicate the situation or learning in library management $[11,1]$.

According to McKenna [11], renovated facilities in the library were more likely to see usage decline, but there was no statistical significant variation in the usage change between renovated and new facilities. On the contrary, recent libraries that upgraded their facilities saw greater usage growth. The lighting in the learning space contributes one of the factors that cause a lack of quality space. This is because the lighting is too bright that will affect user's vision and cause some not comfortable and dissatisfaction [12]. Aspects of temperature (e.g. cold or heat) extreme also has a negative relationship with the individual requirements [13]. All of these issues affect the valuation of the users toward services offered by the library. Consequently, there is an urgent need to improve the quality of library services in regards to the facility learning space available so that users can have a positive perception.

In fact, the assessment of this study hope that it is able to translate a given space (e.g. Iqra' Room) that meet the needs and satisfaction of the users themselves [14]. Thus, there was a need based on the elaboration above to conduct a study in identifying the satisfaction level of preparation facility in the library learning space, taking into account aspects of lighting, ventilation, color, sound effects, furniture and size. In this study, several objectives have been set to achieve the following goals:

(a) To identify the level of satisfaction in the learning space of the library.

(b) To identify the dominant factor affecting the learning space in the library towards library user satisfaction.

(c) To identify, compare and contrast the learning space facility with level of user satisfaction.

\section{Methods}

The survey method of research was employed to achieve the research objectives. The numbers of population in this study is a total of 15000 students by referring to Table Krejcie and Morgan [15]. However, the sample size obtained was 375 respondents. The instrument used was a questionnaire that was distributed to a total number of 375 respondents. The instrument used was a questionnaire that was distributed to a total number of 375 respondents. The method of convenience sampling was used in this study. This sampling method is based on the non-probabilistic sampling technique, where subjects are selected in an unstructured manner from the population frame. The part of the population that is library user who use the room Iqra' is selected. From 375 sample respondents' only 339 questionnaires can be returned. According to Konting [16], a survey study is a study that takes data in a specific time and often using questionnaires. It is also a specific method to collect information about a group of large populations [17]. Among the features of this survey, it is of extensive use because they are used to represent different types of questions. In addition, 
the method of operation and data collection is easy and fast. The function of this survey can continue to collect responses from the subjects in describing the phenomenon being studied. After that, the analysis of the pilot study was conducted to obtain the reliability (i.e. Cronbach Alpha) of the instrument. Abortion and maintenance items specified after the instrument were analyzed using Rasch measurement model with Winstep software version 3.69.11. To conclude, the actual study was conducted to identify the satisfaction level of facility space.

\section{Results}

Table 1 indicates the mean score of the learning space (i.e. Iqra' Room) in the library towards library user satisfaction. The mean score for the lighting elements indicate the lowest level of 3.27 in the group tendency of respondents to a simple user satisfaction. In fact, the mean score under the same groups for ventilation element were 3.45, sound effects (3.50), size (3.52) and color (3.65). In contrast, the mean values in furniture elements indicate a high tendency score of 3.75 . Thus, it is shows that the furniture elements provided by the University Tun Hussein Onn Malaysia library do meet with the user satisfaction when they use an Iqra' room.

Table 1. The mean scores on the facility learning space.

\begin{tabular}{llll}
\hline No & Facility & Mean Score & Interpretation \\
\hline 1 & Lighting & 3.27 & Moderate \\
2 & Ventilation & 3.45 & Moderate \\
3 & Furniture & 3.75 & High \\
4 & Sound effect & 3.50 & Moderate \\
5 & Size & 3.52 & Moderate \\
6 & color & 3.65 & Moderate \\
Overall Satisfaction & 3.50 & Moderate \\
\hline
\end{tabular}

Scale $1.00-2.33=$ Low, $2.34-3.67=$ Moderate, $3.68-5.00=$ High

Based on Table 2, the elements or factors affecting user satisfaction of learning space facility are arranged in descending order according to the mean logit and mean scores. Bond \& Fox [18] noted that the mean value of the lowest logit are ready to be agreed upon and as a benchmark measurement that these factors are dominant among other factors. Next, each element will be discussed based on the analysis accordingly.

Table 2. Value mean and mean logit for the elements of the learning space.

\begin{tabular}{llllll}
\hline No & Element & $\begin{array}{l}\text { Mean } \\
\text { Logit }\end{array}$ & $\begin{array}{l}\text { Mean } \\
\text { Score }\end{array}$ & $\begin{array}{l}\text { Satisfaction } \\
\text { Level }\end{array}$ & $\begin{array}{l}\text { Tendency } \\
\text { Level }\end{array}$ \\
\hline 1 & Lighting & 0.32 & 3.27 & Low & Moderate \\
2 & Ventilation & 0.11 & 3.45 & & Moderate \\
3 & Furniture & 0.01 & 3.50 & & High \\
4 & Sound effect & -0.01 & 3.52 & & Moderate \\
5 & Size & -0.18 & 3.65 & & Moderate \\
6 & color & -0.41 & 3.75 & High & Moderate \\
\hline
\end{tabular}

Table 3 indicates that there is a high significance between the frequencies of lighting elements with the groups of Iqra' room. The frequency of use Iqra' room make the difference in overall user satisfaction in lighting elements which is $t$ value is 2.03 and $p$ value is 0.0429 . Therefore, this result indicates a significant difference toward user satisfaction of lighting elements between the frequencies of use of Iqra' room and the other groups.

Table 3. Comparison of the frequency of use of space (lighting) with user satisfaction.

\begin{tabular}{llllc}
\hline No & $\begin{array}{l}\text { Factor/ } \\
\text { Construct }\end{array}$ & $\boldsymbol{t}$ & $\boldsymbol{p}$ & Results \\
\hline 1 & Lighting & 1.65 & 0.0935 & No Significant Difference \\
2 & Lighting & 2.03 & 0.0429 & Significant Difference \\
3 & Lighting & 1.73 & 0.0851 & No Significant Difference \\
4 & Lighting & 0.69 & 0.4886 & No Significant Difference \\
5 & Lighting & 0.00 & 1.000 & No Significant Difference \\
6 & Lighting & 0.79 & 0.4296 & No Significant Difference \\
\hline
\end{tabular}

Table 4 indicates the results of the analysis between groups using the frequency Iqra' room with furniture element toward user satisfaction on learning space facilities. The results show that frequency of Iqra' room usage with the furniture elements, which $t$ value is 2.47 and the $p$ value is 0.0136 . This result indicates a significant difference toward user satisfaction of furniture elements with the frequency of use each week, per month and others.

Table 4. Comparison of the frequency of furniture toward user satisfaction.

\begin{tabular}{lllll}
\hline No & $\begin{array}{l}\text { Factor/ } \\
\text { Construct }\end{array}$ & $\boldsymbol{t}$ & $\boldsymbol{p}$ & Results \\
\hline 1 & Furniture & 1.37 & 0.17 & No Significant Difference \\
2 & Furniture & 0.20 & 0.8424 & No Significant Difference \\
3 & Furniture & 1.83 & 0.0684 & No Significant Difference \\
4 & Furniture & 2.47 & 0.0136 & Significant Difference \\
5 & Furniture & 0.90 & 0.3705 & No Significant Difference \\
6 & Furniture & 3.80 & 0.0001 & No Significant Difference \\
\hline
\end{tabular}

In addition, the results of sound effect elements show that there were significant differences occurred between the groups. Unlike other elements, these elements of sound effect indicate there is a small and insignificant difference where the value of $t$ obtained is 0.30 , while the $p$-value is 0.7634 (Table 5). This result indicated is a small difference between the groups (i.e. every week) and each month was indicate not significant and frequent use Iqra' toward sound effects on learning room facilities. Thus, there is significant difference between Group 1 and Group 4 which is more than $2 t$ value are $2.11,2.26,3.40,2.98$ and 2.85 and $p$-value less than 0.05 which are $0.0364,0.0248,0.0008,0.0029$ and 0.0045 .

Table 5. differences in the frequency of use of space (sound effects) to the level of user satisfaction.

\begin{tabular}{lllll}
\hline No & $\begin{array}{l}\text { Factor/ } \\
\text { Construct }\end{array}$ & $\boldsymbol{t}$ & $\boldsymbol{p}$ & Results \\
\hline 1 & Sound Effect & 2.11 & 0.0346 & Significant Difference \\
2 & Sound Effect & 2.26 & 0.0248 & Significant Difference \\
3 & Sound Effect & 3.40 & 0.0008 & Significant Difference \\
4 & Sound Effect & 0.30 & 0.7634 & No Significant Difference \\
5 & Sound Effect & 2.98 & 0.0029 & Significant Difference \\
6 & Sound Effect & 2.85 & 0.0045 & Significant Difference \\
\hline
\end{tabular}


From the analysis carried out by elements of the size of the learning spaces facility in Table 6, shows that there are differences between groups of frequency of use Iqra' Room with a value of $t$ which is $0.28,0.86,0.59,1.24,0.69$ and 0.68 , while the $p$-value is $0.7830,0.3912,0.5547,0.2153$, 0.4876 and 0.4970 . However, these findings showed small differences and not significant because it is less than $2.0 t$ and $p$ exceeds 0.05 .

Table 6. Comparison of the frequency of use of space (size) with the level of user satisfaction.

\begin{tabular}{lllll}
\hline No & $\begin{array}{l}\text { Factor/ } \\
\text { Construct }\end{array}$ & $\boldsymbol{t}$ & $\boldsymbol{p}$ & Results \\
\hline 1 & Size & 0.28 & 0.7830 & No Significant Difference \\
2 & Size & 0.86 & 0.3912 & No Significant Difference \\
3 & Size & 0.59 & 0.5547 & No Significant Difference \\
4 & Size & 1.24 & 0.2153 & No Significant Difference \\
5 & Size & 0.69 & 0.4876 & No Significant Difference \\
6 & Size & 0.68 & 0.4970 & No Significant Difference \\
\hline
\end{tabular}

The results of the facility learning space as shown in Table 7 , indicate that there is differences between groups in frequency of use Iqra' Room with a value of $t$ is $0.17,1.38$, $1.30,1.49,1.35$ and 0.25 , while the $p$-value is $0.4825,0.1760$, $0.2025,0.1381,0.1774$ and 0.8002 . However, these findings have shown that these differences were small and not significant because it is less than $2.0 \mathrm{t}$ and $\mathrm{p}$ is 0.05 .

Table 7. Comparison of the frequency of use of space (color) with user satisfaction.

\begin{tabular}{lllll}
\hline No & $\begin{array}{l}\text { Factor/ } \\
\text { Construct }\end{array}$ & $\boldsymbol{t}$ & $\boldsymbol{p}$ & Results \\
\hline 1 & Color & 0.17 & 0.4825 & No Significant Difference \\
2 & Color & 1.38 & 0.1760 & No Significant Difference \\
3 & Color & 1.30 & 0.2025 & No Significant Difference \\
4 & Color & 1.49 & 0.1381 & No Significant Difference \\
5 & Color & 1.35 & 0.1774 & No Significant Difference \\
6 & Color & 0.25 & 0.8002 & No Significant Difference \\
\hline
\end{tabular}

Table 8 shows there is significant difference between the groups of Iqra' room with the ventilation element toward learning space facility. Hence, the result of this study indicates that the difference in overall satisfaction regarding the color element is in group 2 with a value of $t$ is 3.11 and 2.70 and $p$-value is 0.0019 and 0.0069 . These results show a significant difference on user satisfaction of various elements between frequencies using Iqra room each week with a group of frequency of use per month and groups of other frequencies.

Table 8. Comparison of the frequency of use of space (ventilation) with user satisfaction.

\begin{tabular}{lllll}
\hline No & $\begin{array}{l}\text { Factor/ } \\
\text { Construct }\end{array}$ & $\boldsymbol{t}$ & $\boldsymbol{p}$ & Results \\
\hline 1 & Ventilation & 0.62 & 0.5346 & No Significant Difference \\
2 & Ventilation & 0.84 & 0.4003 & No Significant Difference \\
3 & Ventilation & 0.57 & 0.5714 & No Significant Difference \\
4 & Ventilation & 3.11 & 0.0019 & Significant Difference \\
5 & Ventilation & 2.70 & 0.0069 & Significant Difference \\
6 & Ventilation & 0.68 & 0.4983 & No Significant Difference \\
\hline
\end{tabular}

Overall, the results of analysis for the third to seven research question shows that there are some groups that have a significant difference on the learning space facility. Therefore, there exists several factors that reject the hypothesis that had been formed during this initial study. The results obtained are shown in the table below. Based on Table 9 which reveals that, users (i.e. student) will definitely use Iqra' room at least once a month. Meanwhile, the sound effect in the facility is an element that affects user satisfaction when using Iqra room.

Table 9. Results of the analysis of the difference frequency of use Iqra' Room of learning space facility.

\begin{tabular}{llll}
\hline No & $\begin{array}{l}\text { Factor/ } \\
\text { Construct }\end{array}$ & Findings & Results \\
\hline 1 & Lighting & Significant Difference & $\mathrm{H}_{0}$ Accepted \\
2 & Ventilation & Significant Difference & $\mathrm{H}_{0}$ Accepted \\
3 & Sound Effect & Significant Difference & $\mathrm{H}_{0}$ Accepted \\
4 & Size & No Significant Difference & $\mathrm{H}_{0}$ Rejected \\
5 & Color & No Significant Difference & $\mathrm{H}_{0}$ Rejected \\
6 & Furniture & Significant Difference & $\mathrm{H}_{0}$ Accepted \\
\hline
\end{tabular}

\section{Conclusions}

This study analyzed and discussed several major issues raised by each division's objectives which refer to the conclusion to the overall findings of the study. Thus, the findings show that satisfaction level of learning space facility (i.e. Iqra' room) provided by the library only at a moderate level. According to this study, even the library has a new building; the quality of services is not achieve toward user satisfaction. The results also showed that the dominant factor in user satisfaction of learning space facilities is furniture. These factors affect many aspects of user satisfaction such as design, durability, and color and more. However, other factors such as lighting, ventilation, sound effects, size and color are less influential toward user satisfaction. In fact, results of this study show that there are two constructs that reject the hypothesis of colors and size. Then, a decision that can be made is that there is no significant difference for both constructs in user satisfaction of learning space facility. While there were significant differences for lighting, ventilation, sound effects and furniture. In this regard, several proposals have been made to form better results in the future. Among these are:

a). Measurement of quality service that is more complete. Library measurement tool such as LibQUAL has been used by many universities. To make use of this measurement tool will produce more accurate results.

b). Comparison of the satisfaction level between public libraries and private libraries. This comparison can distinguish the policy service, the functionality of facilities offers and see performance between public and private university libraries in Malaysia. The results will be better if the scope is extended by the respondents from universities throughout the country. 
c). The extended scope of the study. The studies need to involve a library user, which consists of lecturers, researchers, academics and university staff on all aspects of the services provided by the library. In addition, the scope of the study is extended by studying in other areas of learning spaces such as lecture halls, seminar rooms and so on.

Finally, library is a valuable asset to the university. The preparation of space for accommodating capacity and meet the users' needs is an important factor or issues in improving the service quality in context. As far as this study is concerned, the library space service quality should be measured in order to determine the effectiveness of the services in meeting user requirements aspects (i.e. size, lighting, ventilation, effect, color and furniture). Those requirement aspects that have reach level of satisfaction can become a guide in creating learning spaces in other places. It is means that this aspect should be emphasized in the planning process of construction. In fact, it is important that the provision of learning spaces could meet the needs of library users.

\section{Acknowledgement}

The authors would like to acknowledge all team members which contribute their time and effort to finish writing this paper. The authors are also indebted to the prior literature research that has been made in any anonymous journal referees related. The author also wishes to thank the editor for extensive assistance in the final revision of the paper to be published.

\section{References}

[1] Shill, H. B., \& Tonner, S. (2003). Creating a Better Place: Physical Improvements in Academic Libraries, 1995-2002. College \& Research Libraries, 64(6), 431-466.

[2] Kashif, M., Hassan, A., \& Hassan, H. (2011). Students and Libraries: The Perspectives of Faculty in a Pakistani University. Asian Journal of University Education Vol, 7(1), 69-84.

[3] Waxman, L. (2006). The coffee shop: Social and physical factors influencing place attachment. Journal of Interior Design, 31(3), 35-53.

[4] Alexander, K., Heywood, C., \& Smith, J. (2006). Integrating stakeholders during community FM's early project phases. Facilities, 24(7/8), 300-313.
[5] Hakala, U., \& Nygrén, U. (2010). Customer satisfaction and the strategic role of university libraries. International Journal of Consumer Studies, 34(2), 204-211.

[6] Montgomery, S. E. (2014). Library space assessment: user learning behaviors in the library. The Journal of Academic Librarianship, 40(1), 70-75.

[7] Hines, S. S. (2014). What Will Libraries Be When They Grow Up?: Responding to the Innovations of Technology and Imagining the Future. Paper presented at the Association of College and Research Libraries 2013 Conference 'Imagine, Innovate, Inspire', 10-13 April, Indianapolis.

[8] O'Connor, S., Miao, H., \& Wang Bassham, M. (2007). Embracing customer service in libraries. Library Management, 28(1/2), 53-61.

[9] Stephen Town, J., Killick, S., van Weerden, A., \& van Weerden, F. (2014). Using LibQUAL $+\circledR$ to identify commonalities in customer satisfaction: the secret to success? Performance Measurement and Metrics, 15(1/2), 23-31.

[10] Adnan, R. N. (2010). Penilaian pengurusan fasiliti di sekolah dasar negeri di Jakarta. (PhD), Universiti Tun Hussein Onn Malaysia.

[11] McKenna, J. (2006). The Quality of Academic Library Building Improvements Has a Positive Impact on Library Usage. 2006, 1(3), 4.

[12] Hebert, P. R., \& Chaney, S. (2012). Using end-user surveys to enhance facilities design and management. Facilities, 30(11/12), 458-471.Adnan, R. N. (2010). Penilaian pengurusan fasiliti di sekolah dasar negeri di Jakarta. (PhD), Universiti Tun Hussein Onn Malaysia.

[13] Wickens, C. D., Lee, J., Liu, Y., \& Becker, S. (2004). An introduction to human factors engineering, 2004: Pearson Education International, Upper Saddle River, NJ.

[14] Filiz, Z. (2007). Service quality of university library: a survey amongst students at Osmangazi University and Anadolu University. İstanbul Üniversitesi Iktisat Fakültesi Ekonometri ve İstatistik Dergisi, 5, 1-19.

[15] Krejcie, R. V., \& Morgan, D. W. (1970). Determining sample size for research activities. Educational and psychological measurement, 30, 607-610.

[16] Konting, M. M. (1990). Kaedah penyelidikan pendidikan: Dewan Bahasa dan Pustaka.

[17] Chua, Y. P. (2006). Kaedah Penyelidikan: McGraww-Hill.

[18] Bond, T. G., \& Fox, C. (2007). Applying the Rasch Model: Fundamental Measurement in the Human Sciences (2nd ed.). New Jersey: Lawrence Erlbaum Associates, Inc. 